RUNNING HEAD: Right-wing populism as a social representation

Staerklé, C., \& Green, E.G.T. (2018). Right-wing populism as a social representation: A comparison across four European countries. Journal of Community and Applied Social Psychology, 28, 430-445. DOI: 10.1002/casp.2369.

Right-wing populism as a social representation:

A comparison across four European countries

Christian Staerklé \& Eva G.T. Green

University of Lausanne, Switzerland

Word count 7782

Address for correspondence:

Christian Staerklé

University of Lausanne

Faculty of Social and Political Sciences

Institute of Psychology

Geopolis Building

CH - 1015 Lausanne

Switzerland

E-mail: christian.staerkle@unil.ch 


\title{
Right-wing populism as a social representation: A comparison across four European countries
}

\begin{abstract}
The rise of right-wing populist parties has been widely discussed across the social sciences during the last decade. Taking a social representational approach, we analyse organising principles and anchoring of right-wing populist thinking across four European countries (France, Netherlands, Switzerland, and the UK). Using European Social Survey data (Round 7), we compare political attitudes and self-appraisals of citizens identifying with right-wing populist, conservative right-wing, and traditional left-wing parties. The findings converge across the four countries to show that right-wing populist identifiers diverge from both leftand right-wing identifiers on vertical (between the "people" and the "elite") and horizontal (between nationals and immigrants) dimensions of differentiation. Depending on the context, right-wing populist identification was fuelled by material and physical insecurity, low political efficacy, and distrust of fellow citizens. We conclude that right-wing populism requires multiple strategies of differentiation within and between groups to justify and sustain itself.
\end{abstract}




\section{Right-wing populism as a social representation: A comparison across four European countries}

The xenophobic stance of right-wing populist parties, their mistrust of elites and institutions, as well as their provocative political style have been widely discussed and analysed in the aftermath of the great recession in 2008 that propelled populist parties to the forefront of European politics (e.g., Judis, 2016; Müller, 2016; Wodak, KhosraviNik \& Mral, 2013). Prior to this special issue, social psychological research has shown little explicit interest in this major political development. Although many recent studies in social psychology and related disciplines have examined support for far-right parties and movements, these studies have primarily focused on the role of anti-immigrant attitudes in far-right support (e.g., Green, Sarrasin, Baur, \& Fasel, 2016; Lucassen \& Lubbers, 2012; Rydgren, 2008).

In this paper, we analyse right-wing populism as a social representation. We argue that right-wing populism attempts to restrict the representation of the nation to a tightly knit and morally superior group composed of like-minded citizens most commonly understood as “ordinary people" (Mols \& Jetten, 2016). In order to reach this goal, it simultaneously values similarity, rejects difference, scorns elites, and devalues institutions. This representation of the nation has spread across contemporary European societies, but is also fiercely debated and contested (Golder, 2016). As such it is endorsed by some and rejected by others, an essential criterion to study a social object as a social representation (Doise, Clémence \& LorenziCioldi, 1993). Adopting a classical social representations research paradigm (Moscovici, 1961 / 2008), we use representative survey data to compare political beliefs and self-appraisals of citizens identifying with a populist right-wing, a conservative right-wing, and a traditional left-wing party across four European countries. 
The social representational approach to populism put forward in this paper (a) demonstrates organising principles of this representation, (b) analyses the anchoring of the representation in citizens' subjective realities and self-appraisals, (c) examines its specificity in relation to representations of the nation associated with traditional left- and right-wing idelogies, and (d) determines the extent of convergence of this representation across four national contexts.

This social representational approach provides a unique contribution to the study of right-wing populism. First, it offers an integrative theoretical framework for a comparative understanding of the content, structure, and context of right-wing populist representations of the nation. Second, it provides a joint explanation of negative attitudes towards institutions and elites on the one hand (vertical differentiation), and on negative attitudes towards cultural difference on the other (horizontal differentiation). Extending the conclusions by Mols and Jetten (2016) to a cross-national, representative sample, we argue that the key process in populist thinking is the cumulation of multiple within- and between group strategies of differentiation. This paper thereby goes beyond the "cultural" demand side explanation of right-wing populist support that frequently focuses on anti-immigration attitudes (Golder, 2016), neglecting the deeper motivation of believing in and belonging to an idealised and imagined nation (Anderson, 1983).

\section{Organising principles of the populist representation}

Organising principles describe the core structure of a social representation and identify the content dimensions towards which individuals take a stance (Doise et al., 1993). Recent research suggests that generic differentiations between social categories (e.g., between "good" and "bad" people, between "winners" and "losers") act as organising principles of different representations of social order (Mouffe, 1993; Staerklé, 2009; 2015; Staerklé, Likki 
\& Scheidegger, 2012). Relatedly, current sociological and political science accounts of populism (e.g., Golder, 2016; Kriesi, 2014; Judis, 2016; Mudde \& Kaltwasser, 2017; Müller, 2016) agree that right-wing populism is organised by a vertical and a horizontal dimension of differentiation between "us" and "them" (Brubaker, 2017).

The vertical dimension of differentiation refers to the relation between "ordinary people" and the political and legal elite within a given country. Right-wing populists mobilise citizens with negative views of elites and institutions. The list of grievances against "those on top" of the society includes accusations of corruption and greed, failure to represent the interests of the "real people", indifference to the economic struggles of ordinary people and condescendence towards their way of life (Rosanvallon, 2008). The democratic system is portrayed as unresponsive to people's demands, and therefore thought to work better without institutional "intermediaries" between the government and the people such as political parties, media, and NGO's (Müller , 2016). The populist leader appears as "rescuing" the people from the claws of immoral elites and dishonest and inefficient institutions, by giving them a voice and directly representing their interests in the political process. The vertical dimension of populism in essence asks for a democracy without institutions.

The horizontal dimension of differentiation refers to the rejection of pluralism, in particular cultural pluralism. Right-wing populists construe a generic opposition between insiders and outsiders that is often tied to cultural differences. Insiders are "people like us", whereas outsiders are those "who are said to threaten our way of life" (Brubaker, 2017, p.1192). Research has amply documented that rejection of cultural diversity is based, on the one hand, on symbolic threat whereby immigrant and refugee populations represent cultural otherness that is said to be incompatible with the values of an idealised and allegedly homogeneous national ingroup. On the other hand, nationals may experience material threat, considering that immigrants strip away ever scarcer job opportunities and abuse tax payer 
money by claiming undue welfare benefits (Riek, Mania \& Gaertner, 2006). An even more sweeping assertion by populist leaders holds that national majorities are actually victims of progressive multicultural policies that are said to unduly benefit cultural minorities (Mols \& Jetten, 2016; Leach, Ayer \& Pedersen, 2007). This horizontal dimension of differentiation has been interpreted as a backlash against the progressive, multicultural and economically liberal policies that have developed in Western countries since the 1970's (Inglehart \& Norris, 2016; Müller, 2016).

In line with prior cross-national survey research on social representations (see Bauer \& Gaskell, 2008), we focus our analysis on the organising principles of the representation (e.g., Doise, Spini \& Clémence, 1999). For the populist representation of the nation, we expect both dimensions of vertical and horizontal differentiation to act as the joint organising principles of right-wing populism, that is, as the core dimensions of the populist identity that define its difference from traditional left- and right-wing identities.

\section{Anchoring}

Following a social representations approach, the populist representation of the nation is socially "anchored" in both objective and subjective realities of individuals (Doise et al., 1993). Social anchoring describes the process through which a representation emanates from specific individual and social circumstances. While social position variables such as age, gender and education level describe objective realities that determine whether individuals identify with populist parties, subjective realities are captured by self-appraisals that give meaning to one's social position. These subjective self-appraisals (e.g., feelings of insecurity and vulnerability) are a priori independent of the populist representation, but they have the potential to generate new representations and further their development and dissemination. 
Accordingly, the second objective is to study the anchoring of the populist representation of the nation by examining the subjective factors that lead people to identify with right-wing populist parties. This approach is akin to the study of the demand side of populism that identifies the fears, grievances and beliefs that lead individuals to endorse populist representations of the nation (Golder, 2016; Rydgren, 2007).

Many studies on populism have shown that economic grievances and disadvantaged social positions (mostly measured by low income, labour market precariousness and low education level) feed resentment towards elites and fuel scapegoating of immigrants (see Rydgren, 2007; 2008; Golder, 2016; Müller, 2016). Explanations in line with the modernization hypothesis interpret populism as a nostalgic reaction to value change in Western societies, leading to rejection of pluralism especially among men, older and less educated generations who see themselves as the losers of globalisation (Inglehart \& Norris, 2017). Other studies, however, have uncovered greater support for far-right parties among young respondents (see Green et al., 2016). We therefore expect male gender and low-status positions to predict right-wing populist identification, but leave open whether age has a positive or negative effect.

In line with our social representational approach, we focus our anchoring analysis on predictors that examine the extent to which respondents' subjective self-appraisal of their position in society determines identification with populist parties (Scheidegger \& Staerklé, 2011). When citizens feel abandoned and betrayed, they are prone to develop an ethos of insecurity, social isolation and mistrust (Castel, 2009). Many feel that social cohesion is declining as they no longer believe in a nation-wide moral community that enables them to trust each other (Larsen, 2013). Existential fears of insecurity, a sense of victimhood and an impression of lacking control over one's life may then lead to the disenchantment with a political system unresponsive to concerns of ordinary people (Kinnvall, 2016). We therefore 
expect populist identification to be associated with a subjective sense of fear and insecurity, with lacking trust in fellow citizens, and with a feeling of lacking political efficacy.

\section{Specificity}

The third objective is to establish the specificity of the populist representation of the nation in relation to traditional left- and right-wing representations. Based on classical social representations research that compares representations across different "social milieus" (Bauer \& Gaskell, 1999; Moscovici, 1961 / 2008), we compare citizens in each of the four countries who identify with a right-wing populist party, with a conservative right-wing party, and with a traditional left-wing party. We chose party identification because we want to study the populist representation with a subsample of respondents that unambiguously endorses populist beliefs. Political parties strive to offer coherent worldviews that define the political priorities of a society and identify its main problems and threats. Individuals who feel close to a political party are expected to recognise and endorse its worldviews (see Bartle \& Bellucci, 2009).

Depending on the countries, populist parties may share positions with both types of mainstream parties (immigrant-hostile positions on the horizontal dimension of differentiation with right-wing parties; more extensive welfare coverage and institutional distrust on the vertical dimension of differentiation with left-wing parties). Our study explores whether the difference between right-wing populist and the respective mainstream party identifiers is of a quantitative (populist parties are on the far right of the left-right continuum) or of a qualitative nature (populist parties are different from both right- and left-wing parties).

\section{Cross-national convergence}

The fourth aim is to assess the cross-national convergence of representations across four European countries: France, Netherlands, Switzerland, and the UK. A high degree of 
convergence would signal that the organising principles of populist representations are common across countries, in spite of possible national specificities, thereby suggesting the presence of a widely shared and potentially influential form of social representation (Doise et al., 1999).

Countries were selected on theoretical and empirical grounds. Theoretically, each of these countries has witnessed the rise of a single populist right-wing party over the last one or two decades (Golder, 2016; Kriesi, 2014; Judis, 2016; Müller, 2016). Empirically, the number of respondents identifying with right-wing populist parties in these countries was sufficiently high $(N>130)$ to yield acceptable statistical power for the group comparisons. We consider that these four countries adequately capture the key processes underlying right-wing populist representations of the nation in Western Europe, thereby paving the way for a more general framework of right-wing populism as a social representation.

\section{Overview of the study}

We assess the organising principles of vertical differentiation with two subdimensions (Institutional trust and System responsiveness) and horizontal differentiation with two sub-dimensions (Material immigrant threat and Cultural diversity threat). The anchoring variables include subjective self-appraisals measured with four sub-dimensions (Material insecurity, Physical insecurity, Interpersonal trust, and Political efficacy) as well as age, gender, education level, citizenship, income, and unemployment history as objective social position variables.

The four objectives require different statistical tests and models. Organising principles and anchoring of the populist representation of the nation are evidenced with a hierarchical logistic regression analysis that accounts for the respective impact of social position variables, subjective self-appraisal and organising principles on populist identification. Specificity of the 
populist representation, in turn, requires within-country party comparison, whereas convergence is based on a between-country national comparison of difference patterns between party identifiers.

We first run an analysis of covariance (ANCOVA) on the four countries to compare, separately for each measure, the three social milieus of populist, right-wing and left-wing party identifiers on the four dimensions of subjective self-appraisal (anchoring variables) and on the four dimensions of vertical and horizontal differentiation (organising principles). Specificity is evidenced with differences between populist party identifiers and identifiers of both left- and right-wing parties. Convergence is evidenced when the difference pattern for the three party identifier categories is consistent across the four countries.

Even though ANCOVA compares anchoring variables and organising principles as a function of party identification, it does not provide information on the relative importance of predictors of populist identification. We therefore ran a complementary logistic regression analysis across the four countries to examine the anchoring of right-wing populist identification in social positions and in self-appraisals, and to test the hypothesis that horizontal and vertical differentiation jointly act as organising principles of right-wing populism. This is evidenced when the two dimensions of differentiation decrease or override effects of positional and anchoring variables in explaining populist right-wing identification. The logistic regression analysis differs from ANCOVA as it (a) simultaneously assesses the relative importance of the various predictors of right-wing populist identification, (b) examines predictors of populist identification as opposed to both left- and right-wing party identification, and (c) analyses all four national contexts at the same time, thereby summarising the key effects across the four countries.

\section{Method}




\section{Participants and procedure}

We used data from the European Social Survey 2014 (Round 7), a large bi-annual international survey on social and political attitudes, from France $(n=1917)$, the Netherlands $(n=1919)$, Switzerland $(n=1532)$, and the UK $(n=2264)$, with an overall $N=7632$. The data are representative of the population aged 16 years and older and were collected with computer-assisted personal interviews (CAPI). ${ }^{1}$

We restricted the sample to respondents who identify with the main right-wing populist party, with the main conservative right-wing party (championing to varying degrees economically liberal and immigrant-hostile policies), or with the main socialist or socialdemocratic left-wing party (advocating to varying degrees inequality reduction and immigrant-friendly policies). Table 1 shows the respective parties for each country as well the number of respondents for each of them. ${ }^{2}$

Mean age for the subsample of identifiers with the three respective parties was 53.7 years $(\mathrm{SD}=18.6)$ in France, 52.0 years $(\mathrm{SD}=17.5)$ in the Netherlands, 50.3 years $(\mathrm{SD} 18.6)$ in Switzerland, and 56.7 years $(\mathrm{SD}=17.5)$ in the UK. Male respondents made up $50.8 \%$ in France, $48.6 \%$ in the Netherlands, $55.0 \%$ in Switzerland, and $50.3 \%$ in the UK. The mean years of education was 12.7 in France, 13.4 in the Netherlands, 11.2 in Switzerland, and 13.3 in the UK. Only small minorities were non-nationals in our subsample (FR: 25, 3.6\%; NL: 8, $1.8 \%$; $\mathrm{CH}: 41,7.5 \%$; UK: 34, 3.6\%).

\footnotetext{
${ }^{1}$ Detailed information on sampling, data collection and cross-national comparative variables (e.g., income level) can be found at www.europeansocialsurvey.org.

${ }^{2}$ Switzerland and the Netherlands have an electoral system with proportional representation in which the observed proportion of right-wing populist identifiers ( $27.3 \%$ and $12.5 \%$, respectively) roughly corresponds to the parliamentary strength of populist parties during data collection in 2014 (26.6\% in Switzerland, $10.0 \%$ in the Netherlands). In the UK and France, parliamentary elections are based on a single member election within constituencies that consequently minimises minority party representation in the respective parliaments. However, in the 2014 election for the European Parliament UKIP won $26.6 \%$ and the FN 24.8\% of the national votes, making them the biggest parties in the respective national components of the European Parliament.
} 


\section{Measures $^{3}$}

For party identification participants reported whether they "feel closer" to a particular political party than to all the other parties, and in case of a positive answer "Which one?".

Income level was measured with ten country-specific income range categories, each corresponding broadly to deciles of the actual household income range in each country.

For unemployment history, respondents were asked whether they had ever been unemployed and seeking work for a period of more than three months (yes, no).

Self-appraisals. Perceived material insecurity was assessed with a subjective evaluation of one's household income. Responses ranged from (1) Living comfortably on ..., (2) Coping on ..., (3) Finding it difficult on ..., to (4) Finding it very difficult on present income.

Perceived physical insecurity was used as a proxy for a general sense of insecurity and measured with an item of perceived safety in public space ("walking alone in this area after dark", 1 = very safe, 4 = very unsafe).

Political efficacy assessed respondents' perceived personal (in-)ability to participate in the political process, a dimension associated with political powerlessness. Political efficacy was measured with three items (e.g., How able [are you] to take an active role in a group involved with political issues?). Responses were given on an 11-point scale ranging from 0 (Not at all able/confident/easy) to 10 (Completely able /confident/ Extremely easy), with higher means indicating higher efficacy. Preliminary principal components analyses showed that the three items loaded on a single factor in all four countries. Cronbach's alpha of the composite score was .76 (FR), .86 (NL), .78 (CH), and .83 (UK).

\footnotetext{
${ }^{3}$ Full description of all measures can be found in the supplementary material.
} 
Interpersonal trust evaluated the perceived moral qualities of an unspecified, generic majority ("most people"). It thereby indicates generalised interpersonal trust, respectively, when reversed, distrust and possibly social isolation. Interpersonal trust was measured with three items (e.g., [...] most people can be trusted, or [...] you can't be too careful in dealing with people?). Responses were given on an 11-point bi-polar scale ranging from 0 to 10, with higher means indicating higher trust. Preliminary principal components analyses showed that the three items loaded on a single factor in all four countries. Cronbach's alpha was .62 (FR), $.66(\mathrm{CH}), .71(\mathrm{NL})$, and $.77(\mathrm{UK})$.

Vertical differentiation. Institutional trust assessed (dis-)trust of political and legal institutions (i.e., "elites") at the national level: (1) politicians; (2) [country's] parliament; (3) political parties; and (4) the legal system. Responses were given on an 11-point scale ranging from 0 (No trust at all) to 10 (Complete trust), with higher means indicating higher trust. Preliminary principal components analyses showed that the four items loaded on a single factor in all four countries. Cronbach's alpha was $.85(\mathrm{FR}), .90(\mathrm{NL}), .85(\mathrm{CH})$, and $.88(\mathrm{UK})$.

System responsiveness evaluated agreement with the claim put forward by populists that the "government" is insensitive to people's demands and needs. It was measured with three items (e.g., How much [does] the political system in [country] allow people like you to have a say in what the government does?). Responses were given on an 11-point scale ranging from 0 (Not at all) to 10 (Completely), with higher means indicating higher responsiveness. Preliminary principal components analyses showed that the three items loaded on a single factor in all four countries. Cronbach's alpha was .78 (FR), .85 (NL), .77 (CH), and .83 (UK). This measure represents a judgement on the responsiveness (and thus legitimacy) of the 
political system, whereas the measure of political efficacy taps the personal ability to intervene in this system. ${ }^{4}$

Horizontal differentiation. Material immigrant threat measured perceived job competition and social scrounging from immigrants. It was assessed with three items (e.g., $[\ldots]$ people who come to live here $[\ldots]$ take jobs away $[\ldots]$, or $[\ldots]$ help to create new jobs?). Responses were given on a bi-polar 11-point scale ranging from 0 to 10 . Cronbach's alpha was .71(FR), .72(NL), .63(CH), and .80(UK).

Cultural diversity threat taps opposition to multiculturalism and support for assimilationism, and was assessed with three items (e.g., Is [country]'s cultural life undermined or enriched by people coming to live here $[\ldots]$ ?). For items 1 and 2 (see Appendix), responses were given on a bi-polar 11-point scale; for item 3 the response scale was from 1 (Agree strongly) to 5 (Disagree strongly). Cronbach's alpha was .65 (FR), .63 (NL), $62(\mathrm{CH})$, and $.69(\mathrm{UK})$. Due to the different response scales, the six material immigrant threat and cultural diversity threat items were standardised and recoded such that higher means indicate greater perceived threat. ${ }^{5}$

\section{Results}

All analyses were carried out with SPSS 24.0. We first present ANCOVA results that establish specificity and convergence of populist representations. Second, we report findings of a binary logistic regression analysis that examines the cross-national anchoring of the

\footnotetext{
${ }^{4}$ Preliminary principal components analyses showed that the six items of the measures of political efficacy and system responsiveness loaded on two separate factors in all four countries. Correlations between the two indicators were $r=.64(\mathrm{FR}), r=.76(\mathrm{NL}), r=.55(\mathrm{CH})$, and $r=.69$ (UK).

${ }^{5}$ Preliminary principal components analyses showed that the six items of the measures of material immigrant threat and cultural diversity threat loaded on a single factor in all four countries. Nevertheless, extensive research on the differences between material and symbolic immigrant threat (Riek et al., 2006) as well as the continuous public debate involving different arguments related to both material and identity-based threat led us to keep the two dimensions separate for the purpose of our analyses.
} 
populist representation (Models 1 and 2) and demonstrates its organising principles (Model $3)$.

\section{Specificity and convergence}

We performed separate ANCOVAS for each of the eight anchoring and organising principle variables, with Country (France vs. Netherlands vs. Switzerland vs. UK) and Party identification (Populist vs. Right-wing vs. Left-Wing party identification) as between-subjects variables. Table 2 shows the F statistics and effect sizes of the three effects of interest (Country, Party and Country x Party). Since we are not concerned with overall country or party means, these are not reported.

Table 2 shows that all effects were significant, suggesting that the overall means of the four countries differed on all dimensions, and so did the means of the populist, right-wing and left-wing identifiers. Moreover, party differences were qualified by the national context. Effect sizes (partial eta squared) were largest for country variation of institutional trust and system responsiveness (vertical differentiation dimensions), for party variation of institutional trust, and for party variation of material immigrant threat and cultural diversity threat (horizontal differentiation dimensions).

Table 3 presents the estimated ANCOVA means for the three groups defined by party identification, corrected for age, gender and education level in order to control for compositional effects of the representative samples. Two simple contrasts tested the mean difference between populist identifiers one the one hand, and right-wing and left-wing identifiers on the other.

Self-appraisals. For material insecurity, contrast analyses revealed that populist identifiers felt more materially insecure than right-wing identifiers across the four countries, and more insecure than left-wing identifiers in France and (marginally) in the Netherlands. 
For physical insecurity, contrast analyses revealed that populist identifiers felt physically more insecure than left-wing identifiers in France, and more insecure than right-wing identifiers in the UK. In the Netherlands, populist identifiers felt more insecure than both other categories. For interpersonal trust, contrast analyses show that in France, the Netherlands and the UK populist identifiers were more distrusting of fellow citizens than both left- and right-wing identifiers. In Switzerland, the difference was significant only with leftwing identifiers. For political efficacy, finally, contrast effects revealed that in France, the Netherlands, and the UK populist identifiers felt less able and less competent to participate in the political process than both left- and right-wing identifiers. In Switzerland, only the difference with right-wing identifiers was significant.

These four self-appraisal analyses suggest that populist identifiers across the four countries do experience greater powerlessness than left- and right-wing identifiers. They also trust their fellow citizens less than the other two categories. They often experience greater physical and material insecurity, though with lower convergence across countries.

Vertical differentiation. Contrast analyses for institutional trust reveal that populist identifiers were more distrustful of political institutions than both right- and left-wing identifiers across the four countries. Findings for system responsiveness show a largely similar pattern as populist identifiers differed from both right- and left-wing identifiers across all contexts. Revealing both specificity and cross-national convergence, populist identifiers across the four countries engaged in greater vertical differentiation, compared to individuals identifying with the main right- or left-wing parties. Populist identifiers in France and the UK were particularly distrustful of institutions and wary about the responsiveness of the system, compared to more trusting Dutch and, even more so, Swiss populist identifiers. 
Horizontal differentiation. Contrast effects for perceived material immigrant threat reveal that populist identifiers reported massively greater material immigrant threat than both right-wing and left-wing identifiers across the four contexts. The pattern for perceived cultural diversity threat was similar to the one of material threat. These findings in turn provide evidence for the specificity and convergence of the right-wing populist position towards horizontal differentiation.

\section{Anchoring and organising principles}

In order to examine the anchoring and organising principles of populist identification, we ran a hierarchical binary logistic regression analysis on populist party identification (as opposed to combined left- and right-wing party identification) (Table 4). Since in this paper we do not focus on country differences of predictors of populist party identification, we pooled the data for the four countries, and entered them in the model as main effect dummy variables (with Netherlands as the reference category).

The findings for Model 1 (with country and positional variables) first revealed a compositional effect of the sample showing that there were relatively less populist party identifiers (among the three party-identifier categories under scrutiny) in France and the UK, compared to Switzerland and the Netherlands. More importantly, and controlling for country variation, men and younger respondents were more likely to identify with right-wing populist parties $^{6}$, much like respondents with a lower level of education, with lower income and those with national citizenship. Unemployment history did not play a role.

\footnotetext{
${ }^{6}$ We also explored the curvilinear relationship between age and populist identification. In a model with country, gender, age and education level as control variables, entering the squared version of the (centered) age variable increased explained variance $(B=-.0003, S E=.0001, p=.025)$, suggesting an inverted $U$ relationship in addition to the linear effect. Inspection of the probability curve of identifying with right-wing populist parties as a function of five-year age categories reveals, however, a more complex age pattern: the general linear trend showing decreasing populist identification with age is inverted between ages 20 and 25 when identification increases from $29.7 \%$ to $38.9 \%$, before dropping sharply around the age of 35 (from $38.9 \%$
} 
Self-appraisal anchoring variables were added in Model 2. Perceived material insecurity was unrelated to populist identification, whereas a positive association was found for perceived physical insecurity. Both low interpersonal trust and low political efficacy were associated with populist identification. All positional effects remained significant after entering the self-appraisals in the model.

In Model 3, we added the organising principles of vertical and horizontal differentiation. For vertical differentiation, institutional distrust predicted populist identification, and so did low system responsiveness. As for horizontal differentiation, the findings revealed strong effects for both material immigrant threat and cultural diversity threat. After entering the four dimensions of vertical and horizontal differentiation in the model, the positional effects remained significant, with the exception of national citizenship that was no longer associated with populist party identification. Self-appraisal effects, however, disappeared completely, suggesting that the organising principles of vertical and horizontal differentiation overrode the effects of physical insecurity, interpersonal trust and political efficacy on populist party identification. ${ }^{7}$

\section{Discussion}

In this study, we analysed right-wing populism as a social representation across four European countries, France, the Netherlands, Switzerland and the UK. Based on classical social representation research (Moscovici, 1961 / 2008), we adopted a novel approach for the study of right-wing populism by cross-nationally comparing populist party identifiers with those identifying with traditional left- and right-wing parties.

to $19.4 \%)$, and then rising again to expected levels around age 50 (30.2\%). Possible age-gender interactions were also explored, but no significant effects were found.

${ }^{7}$ We ran the logistic regression also with a single threat indicator. While its effect was strong $(B=1.56, S . E .=$ .11 , Wald $=223.52, p<.001$ ), all other effects in the model remained identical in essence. 


\section{Specificity and convergence}

The ANCOVA difference patterns between the three party identifier categories reveal the specificity of populist representations compared to traditional left- and right-wing representations. Cross-national examination of these patterns provide an indication of their convergence across the four countries.

For horizontal differentiation, traditional right-wing identifiers (RW) were consistently located between right-wing populists (POP) and traditional left-wing party identifiers (LW), producing a POP - RW - LW sequence. The overall similarity of results regarding cultural and material immigrant threat further suggests that in respondents' heads, the difference between these two forms of perceived threat is hardly relevant (see also Golder, 2016; Green \& Staerklé, 2013).

For vertical differentiation, however, assessed with institutional trust and system responsiveness, left-wing identifiers were located between the other two groups (POP - LW RW) in Switzerland and the UK. The relatively large effect sizes for overall country differences further suggest that cross-national differences are important on this vertical dimension of differentiation. Right-wing populism is therefore not simply an extreme form of right-wing conservatism (that is, quantitatively different), but — depending on the national context - may combine elements of both right-wing and left-wing political disourse. It should therefore be considered as qualitatively different from mainstream political ideologies.

To sum up, populist party identifiers in all four contexts set themselves apart from both left- and right-wing supporters on the joint organising principles of vertical and horizontal differentiation, providing evidence for the specificity of right-wing populist representations of the nation. And even though the interaction effects between country and party were significant, their effect sizes appear to be minor compared to the large main effects 
of party, especially for horizontal differentiation. These findings further underscore the often extreme, yet convergent political positioning of European right-wing populist party identifiers on both dimensions of differentiation. Future research should nevertheless analyse in more detail the underlying reasons and the possible social psychological implications of these country differences (see Wodak et al, 2013, for a detailed analysis of country differences of right-wing populism).

\section{Anchoring}

Model 1 of the hierarchical logistic regression analysis in turn revealed that the prototypical right-wing populist identifier is a 25-34 year old male with a low level of education and with a low income holding a national passport, thereby largely confirming prior research on the demand side of right-wing populism (Rydgren, 2007; Müller, 2016). It is noteworthy that the negative effect of age was largely unaffected by the introduction of selfappraisals and organising principles in models 2 and 3, suggesting that factors other than those assessed in our study are responsible for this effect. This finding runs counter commonsense conceptions of right-wing populism that is more often associated with "angry, old men" than with the younger generations. It is also at odds with a generational value conflict explanation (Inglehart \& Norris, 2016). At the same time, other research has also uncovered this effect (see Golder, 2016; Green et al, 2016). Many recent (and not necessarily right-wing populist) political developments have been explained by a strong involvement of disillusioned young generations, for example the Labour party success in the 2017 UK General Election (Young, 2018), or the 2017 electoral success of the far-right Austrian People's party under the leadership of 31-year old Sebastian Kurz. Age therefore seems to play a complex and ambivalent role in explaining support for right-wing populism. Our additional analyses indeed revealed a complex curvilinear pattern according to which the cohort aged 25 to 34 in particular was overrepresented among right-wing populist identifiers. One interpretation of 
this finding is that around the age of 25 , many young people may realise a gap between their expectations and the reality of their precarious and uncertain lives, leading to disillusionment and the search for certainty and positive identity found in populist discourse. Future research should examine the specific reasons that explain why younger voters are attracted to rightwing populist representations of the nation. Longitudinal analyses may disentangle age and cohort effects.

The results of model 2 show that populist identifiers, controlling for positional variables, felt politically more powerless relative to the other two categories, expressed lower trust in fellow citizens, and felt physically more insecure. This generalised social distrust associated with pervasive feelings of insecurity may be symptomatic of a perceived breakdown of social cohesion, stability and continuity (Rosanvallon, 2008). Yet, the positive relationship with interpersonal distrust does not necessarily mean that right-wing populism is the outcome of social alienation and isolation, an explanation of populism that has received little empirical support (Rydgren, 2007). Instead, we suspect that it indicates a defensive and self-protective worldview that motivates citizens to affiliate themselves with similar and therefore trustworthy others in a safe and irrefutably superior, but fictitious national ingroup.

Political powerlessness prevalent for this category further suggests that the populist representation is marked by lacking political legitimacy and a sense of victimisation. This interpretation is in line with the conjecture that populism is a form of "inverted" identity politics (Müller, 2016) in which populist leaders portray “ordinary people” as a victimised majority, betrayed by elites who allegedly reserve better treatment for immigrants (Mols \& Jetten, 2016). Populist leaders seem to denounce a broken social contract between the rulers and the ruled, a contract that in their view can only be revalidated with the help of a strong leader who directly represents their values and interests. 
Material insecurity was the only self-appraisal variable that was no longer a significant predictor of populist identification in the regression analysis, compared to the univariate ANCOVA that showed that populist identifiers were more materially insecure than most of their left- and right-wing counterparts. This finding suggests that the relationship between material insecurity and populist identification is partially accounted for by positional variables such as income and education level.

\section{Organising principles}

Consistent with the large effect sizes found for the effect of party identification on the four measures of vertical and horizontal differentiation, model 3 of the logistic regression analysis revealed that when the effects of social position and self-appraisals were controlled for, both vertical and horizontal differentiation remained by far the most important predictors of right-wing populist identification. Moreover, they cancelled out the effects of selfappraisals, suggesting that right-wing populism is first of all driven by a desire for differentiation and positive group membership. These findings confirm that vertical differentiation (between "ordinary people" and authorities/institutions) and horizontal differentiation (between nationals and immigrants) jointly act as organising principles of the populist representation of the nation.

\section{Limits}

This study has several shortcomings that must be acknowledged. First, the selection of countries induces specific interpretations of the social representation of populism. The inclusion of other countries with recent surges of right-wing populism (such as Hungary, Austria, or the U.S.) would possibly lead to new insights regarding the anchoring of populist representations. However, given the cross-national consistency of the organising principles, we are confident that the four countries under scrutiny capture the essential dynamics 
underlying populist representations of the nation, at least in Western Europe. Second, there are limits concerning the data themselves. While European Social Survey data are often considered the best available cross-national survey data, the internal consistency of some indicators was not satisfying and therefore potentially unstable. More importantly, measures of the key concepts used in our approach can be improved. Even though we believe that negative attitudes towards institutions and immigrants necessarily imply (negative) differentiation, future research should devise less evaluative measures of differentiation. Similarly, the vertical dimension of differentiation was measured only through attitudes towards (political) institutions and authorities. Future research should include measures relating to distrust in (economic, intellectual and cultural) elites more generally that often features in accounts of populism (Golder, 2016).

\section{Conclusion}

Our findings suggest that right-wing populism relies on a coherent social representation of the nation that is shared across the four countries. The national ingroup is represented as a culturally and normatively homogeneous group of upright citizens embodying the nation's purported founding values (Mudde \& Kaltwasser, 2017). In order to sustain representations of a "pure" ingroup, cultural outgroups become necessarily threatening in the populist worldview. Put otherwise, since the generalised rejection of difference is constitutive of the populist representation of the nation, diversity threat does not require any empirical justification: the representation of belonging to a tightly knit (“entitative”, Yzerbyt, Castano, Leyens, \& Paladino, 2000) and morally superior national ingroup is sufficient (see Brewer, 1999). Future research should examine the extent to which this belongingness hypothesis is able to account for right-wing populism across European and other countries. 
Maybe the most striking feature of these findings is that right-wing populism cumulates virtually all possible forms of exclusionary differentiation: it not only leads to a distancing from immigrants, but also from institutions, authorities, and fellow citizens. Interpersonal similarity freed from institutional constraints becomes the sole basis of a valid social bond, whereas difference - within and between groups — is by definition negative and threatening. In short, populism requires multiple forms of otherness to justify and sustain itself. 


\section{References}

Anderson, B. (1983). Imagined communities: Reflections on the origin and spread of nationalism. London: Verso.

Bartle, J., \& Bellucci, P. (Eds.)(2009). Political parties and partisanship: Social identity and individual attitudes. ECPR Studies in European Political Science. Milton Park, UK: Routledge.

Bauer, M., \& Gaskell, G. (2008). Towards a paradigm for research on social representations. Journal for the Theory of Social Behaviour, 29,163-186. DOI: 10.1111/14685914.00096.

Bauer, M., \& Gaskell, G. (2008). Social representations theory: A progressive research programme for social psychology. Journal for the Theory of Social Behaviour, 38, 335-353. DOI: 10.1111/j.1468-5914.2008.00374.x

Brewer, M. (1999). The psychology of prejudice: Ingroup love and outgroup hate? Journal of Social Issues, 55, 429-444. DOI: 10.1111/0022-4537.00126.

Brubaker, R. (2017). Between nationalism and civilizationism: the European populist moment in comparative perspective. Ethnic and Racial Studies, 40, 1191-1226, DOI: 10.1080/01419870.2017.1294700.

Castel, R. (2009). La montée des incertitudes. Travail, protections, statut de l'individu. Paris : Seuil.

Doise, W., Clémence A., \& Lorenzi-Cioldi F. (1993). The quantitative analysis of social representations. Hemel Hempstead: Harvester Wheatsheaf.

Doise, W., Spini, D., \& Clémence, A. (1999). Human rights studied as social representations in a cross-national context. European Journal of Social Psychology, 29, 1-29. DOI: 10.1002/(SICI)1099-0992(199902)29:1<1::AID-EJSP909>3.0.CO;2-\#.

Golder. M. (2016). Far right parties in Europe. Annual Review of Political Science, 19, $477-$ 497. DOI: 10.1146/annurev-polisci-042814-012441.

Green, E. G. T., \& Staerklé, C. (2013). Migration and multiculturalism. In L. Huddy, D. O. Sears, \& J. Levy (Eds.) Oxford Handbook of Political Psychology (2 ${ }^{\text {nd }}$ ed., pp. 852889).Oxford, UK: Oxford University Press. 
Green, E. G. T., Sarrasin, O., Baur, R., \& Fasel, N. (2016). From stigmatized immigrants to radical right voting: A multilevel study on the role of threat and contact. Political Psychology, 37, 465-480. DOI: 10.1111/pops.12290.

Inglehart, R.F., \& Norris, P. (2016). Trump, Brexit, and the rise of populism: Economic havenots and cultural backlash. Faculty Research Working Paper Series 16-026. Harvard Kennedy School, Harvard University.

Judis, J. (2016). The populist explosion: How the great recession transformed American and European politics. New York: Columbia Global Reports.

Kinvall, C. (2016). Fear, insecurity and the (re-)emergence of the far-right in Europe. In P. Nesbitt-Larking, C. Kinnvall, \& T. Capelos (Eds). The Palgrave Handbook of Global Political Psychology (pp. 316-335). London: Palgrave McMillan.

Kriesi, H. (2014). The populist challenge. West European Politics, 37, 361-378. DOI:10.1080/01402382.2014.887879.

Larsen, C. A. (2013). The rise and fall of social cohesion: The construction and deconstruction of social trust in the US, UK, Sweden and Denmark. Oxford: Oxford University Press.

Leach, C.W., Iyer, A., \& Pedersen, A. (2007). Angry opposition to government redress: When the structurally advantaged perceive themselves as relatively deprived. British Journal of Social Psychology, 46, 191-204. DOI: 10.1348/014466606X99360.

Lucassen, G., \& Lubbers, M. (2012). Who fears what? Explaining far-right-wing preference in Europe by distinguishing perceived cultural and economic ethnic threats. Comparative Political Studies, 45, 547-574. DOI: 10.1177/0010414011427851.

Mols, F., \& Jetten, J. (2016). Explaining the appeal of populist right-wing parties in times of economic prosperity. Political Psychology, 37, 275-292. DOI: 10.1111/pops.12258.

Moscovici, S. (1961/2008). Psychoanalysis: Its image and its public. Cambridge, UK: Polity Press.

Mouffe, C. (1993). The return of the political. London: Verso.

Mudde, C. (2007). Populist radical right parties in Europe. Cambridge, UK: CUP. 
Mudde, C., \& Kaltwasser, C.R. (2017). Populism: A very short introduction. Oxford, UK: OUP.

Müller, J.-W. (2016). What is populism? Philadelphia, PA: University of Pennsylvania Press.

Riek, B. M., Mania, E. W., \& Gaertner, S. L. (2006). Intergroup threat and outgroup attitudes: A meta-analytic review. Personality and Social Psychology Review, 10, 336-353. DOI: $10.1207 /$ s15327957pspr1004_4.

Rosanvallon P. (2008). Counter-democracy: Politics in an age of distrust. Cambridge, UK: Cambridge University Press.

Rydgren, J. (2007). The sociology of the radical right. Annual Review of Sociology, 33, 241262. DOI: 10.1146/annurev.soc.33.040406.131752.

Rydgren, J. (2008). Immigration sceptics, xenophobes or racists? Radical right-wing voting in six West European countries. European Journal of Political Research, 47, 737-765. DOI: $10.1111 /$ j.1475-6765.2008.00784.x.

Scheidegger, R., \& Staerklé, C. (2011). Political trust and distrust in Switzerland: A normative analysis. Swiss Political Science Review, 17, 164-187. DOI: 10.1111/j.1662-6370.2011.02010.x.

Staerklé, C. (2009). Policy attitudes, ideological values and social representations. Social and Personality Psychology Compass, 3, 1096-1112. DOI: 10.1111/j.17519004.2009.00237.x.

Staerklé, C. (2015). Social order and political legitimacy. In G. Sammut, E. Andreouli, G. Gaskell, \& J. Valsiner (Eds.), The Cambridge Handbook of Social Representations (pp. 280-294). Cambridge: Cambridge University Press.

Staerklé, C., Likki, T., \& Scheidegger, R. (2012). A normative approach to welfare attitudes. In S. Svallfors (Ed.) Contested Welfare States: Welfare Attitudes in Europe and Beyond (pp. 81-118). Stanford: Stanford University Press.

Wodak, R., KhosraviNik, M. \& Mral, B. (Eds)(2013). Right-wing populism in Europe. London: Bloomsbury.

Young, L. (2018). Rise. How Jeremy Corbyn inspired the young to create a new socialism. London: Simon \& Schuster. 
Yzerbyt, V., \& Castano, E., Leyens, J.-P., \& Paladino, M.P. (2000). The primacy of the ingroup: The interplay of entitativity and identification. European Review of Social Psychology, 11, 257-295. DOI: 10.1080/14792772043000059. 
Table 1

Sub-sample descriptives for France, the Netherlands, Switzerland, and the UK

\begin{tabular}{|c|c|c|c|c|c|c|c|c|c|c|c|c|}
\hline & Populist Party & $\mathrm{N}$ & $\%$ & Right-Wing Party & $\mathrm{N}$ & $\%$ & $\begin{array}{l}\text { Left-Wing } \\
\text { Party }\end{array}$ & $\mathrm{N}$ & $\%$ & $\begin{array}{l}\text { Other } \\
\text { parties }\end{array}$ & $\%$ & $\begin{array}{c}\text { Total } \\
\text { Party } \\
\text { identifiers }\end{array}$ \\
\hline France (FR) & $\begin{array}{l}\text { Front National } \\
\qquad(\mathrm{FN})\end{array}$ & 155 & 15.8 & $\begin{array}{l}\text { Union pour un } \\
\text { mouvement } \\
\text { populaire (UMP) }\end{array}$ & 274 & 27.9 & $\begin{array}{l}\text { Socialist } \\
\text { Party }\end{array}$ & 274 & 27.9 & 278 & 28.3 & 981 \\
\hline $\begin{array}{l}\text { Netherlands } \\
\text { (NL) }\end{array}$ & $\begin{array}{l}\text { Party for } \\
\text { Freedom } \\
\text { (PVV) }\end{array}$ & 132 & 12.5 & $\begin{array}{l}\text { People's Party for } \\
\text { Freedom and } \\
\text { Democracy (VDD) }\end{array}$ & 214 & 20.3 & $\begin{array}{l}\text { Labour } \\
\text { Party }\end{array}$ & 111 & 10.5 & 596 & 56.6 & 1053 \\
\hline $\begin{array}{l}\text { Switzerland } \\
\qquad(\mathrm{CH})\end{array}$ & $\begin{array}{l}\text { Swiss People's } \\
\text { Party (SVP) }\end{array}$ & 217 & 27.3 & $\begin{array}{c}\text { Radical-Liberal } \\
\text { Party }\end{array}$ & 114 & 14.4 & $\begin{array}{l}\text { Socialist } \\
\text { Party }\end{array}$ & 216 & 27.2 & 247 & 31.1 & 794 \\
\hline $\begin{array}{l}\text { United } \\
\text { Kingdom } \\
(\mathrm{UK})\end{array}$ & $\begin{array}{l}\text { Independence } \\
\text { Party (UKIP) }\end{array}$ & 166 & 14.2 & $\begin{array}{c}\text { Conservative Party } \\
\text { (Tories) }\end{array}$ & 373 & 32.0 & $\begin{array}{l}\text { Labour } \\
\text { Party }\end{array}$ & 415 & 35.6 & 211 & 18.1 & 1165 \\
\hline
\end{tabular}


Table 2

ANCOVA: F statistics and effect sizes of between-subjects factors Country and Party

\begin{tabular}{|c|c|c|c|c|c|c|}
\hline & \multicolumn{2}{|c|}{ Country } & \multirow{2}{*}{$\begin{array}{c}\text { Party } \\
F(2,2596)\end{array}$} & \multicolumn{3}{|c|}{ Country x Party } \\
\hline & $F(3,2596)$ & $\eta_{\mathrm{p}}^{2}$ & & $\eta_{\mathrm{p}}^{2}$ & $F(6,2596)$ & $\eta_{\mathrm{p}}^{2}$ \\
\hline \multicolumn{7}{|l|}{ Anchoring (Self-appraisals) } \\
\hline Material insecurity & $42.73 * * *$ & .047 & $28.36 * * *$ & .021 & $7.21 * * *$ & .016 \\
\hline Physical insecurity & $28.36 * * *$ & .032 & $12.73 * * *$ & .010 & $7.44 * * *$ & .017 \\
\hline Interpersonal trust & $51.22 * * *$ & .056 & $37.27 * * *$ & .028 & $5.13 * * *$ & .012 \\
\hline Political efficacy & $91.28 * * *$ & .095 & $19.47 * * *$ & .015 & $3.43 * *$ & .008 \\
\hline \multicolumn{7}{|l|}{ Organising principles } \\
\hline \multicolumn{7}{|l|}{ Vertical differentiation } \\
\hline Institutional trust & $174.70 * * *$ & .168 & $183.08 * * *$ & .124 & $20.26^{* * *}$ & .045 \\
\hline System responsiveness & $211.16^{* * *}$ & .196 & $111.10 * * *$ & .079 & $11.41 * * *$ & .026 \\
\hline \multicolumn{7}{|l|}{ Horizontal differentiation } \\
\hline Material immigrant threat & $62.31 * * *$ & .067 & $255.97 * * *$ & .165 & $4.02 * * *$ & .009 \\
\hline Cultural diversity threat & $76.83 * * *$ & .082 & $280.81 * * *$ & .178 & $5.84 * * *$ & .013 \\
\hline
\end{tabular}

Note: ${ }^{* * *} p<.001, * * p<.01, * p<.05,+\mathrm{p}<.10$. 
Table 3

ANCOVA: Estimated means for populist, right-wing and left-wing identifiers, corrected for country, age, gender and education level

\begin{tabular}{|c|c|c|c|c|c|c|c|c|c|c|c|c|}
\hline & \multicolumn{3}{|c|}{ France } & \multicolumn{3}{|c|}{ Netherlands } & \multicolumn{3}{|c|}{ Switzerland } & \multicolumn{3}{|c|}{ UK } \\
\hline & Pop & Right & Left & Pop & Right & Left & Pop & Right & Left & Pop & Right & Left \\
\hline \multicolumn{13}{|l|}{ Anchoring (Self-appraisals) } \\
\hline Material insecurity & 2.05 & $1.79 * * *$ & $1.72 * * *$ & 1.85 & $1.48 * * *$ & $1.68+$ & 1.42 & $1.25 *$ & 1.53 & 1.90 & $1.58 * * *$ & 1.97 \\
\hline Physical insecurity & 2.25 & 2.17 & $1.88 * * *$ & 2.17 & $1.90 * *$ & $1.89 * *$ & 1.76 & 1.71 & 1.70 & 2.22 & $1.90 * * *$ & 2.15 \\
\hline Interpersonal trust & 4.40 & $5.07 * * *$ & $5.60 * * *$ & 5.33 & $6.19 * * *$ & $6.15 * * *$ & 5.89 & 6.16 & $6.27 *$ & 5.30 & $5.87 * * *$ & $5.67 *$ \\
\hline Political efficacy & 3.32 & $3.92 * *$ & $4.28 * * *$ & 3.35 & $4.02 * *$ & $4.25 * *$ & 5.57 & $6.09 *$ & 5.63 & 3.59 & $4.53 * * *$ & $4.05^{*}$ \\
\hline \multicolumn{13}{|l|}{ Organising principles } \\
\hline \multicolumn{13}{|l|}{ Vertical differentiation } \\
\hline Institutional trust & 2.48 & $3.85 * * *$ & $4.60 * * *$ & 3.55 & $5.74 * * *$ & $5.86 * * *$ & 5.49 & $6.21 * * *$ & $5.99 * *$ & 2.91 & $5.20 * * *$ & $4.37 * * *$ \\
\hline System responsiveness & 2.10 & $3.05 * * *$ & $3.82 * * *$ & 3.10 & $4.78 * * *$ & $4.96 * * *$ & 5.15 & $6.20 * * *$ & $5.78 * * *$ & 2.60 & $4.40 * * *$ & $3.67 * * *$ \\
\hline \multicolumn{13}{|l|}{ Horizontal differentiation } \\
\hline Material immigrant threat & 0.86 & $0.19 * * *$ & $-0.24 * * *$ & 0.63 & $0.08 * * *$ & $-0.20 * * *$ & 0.13 & $-0.34 * * *$ & $-0.61 * * *$ & 0.83 & $0.05 * * *$ & $-0.09 * * *$ \\
\hline Cultural diversity threat & 0.91 & $0.31 * * *$ & $-0.25 * * *$ & 0.37 & $.00 * * *$ & $-0.34 * * *$ & 0.28 & $-0.09 * * *$ & $-0.57 * * *$ & 0.94 & $0.28 * * *$ & $0.05 * * *$ \\
\hline
\end{tabular}

Note: Significance levels in the Right-wing columns refer to contrast 1 (Populist vs. Right-wing), and in the Left-wing columns to contrast 2 (Populist vs.

Left-wing). Populist identifier means are in italics.

$* * * p<.001, * * p<.01, * p<.05,+\mathrm{p}<.10$. 


\section{Table 4}

Binary logistic regression analysis on populist party identification across four national contexts $(\mathrm{N}=2384)$

\begin{tabular}{|c|c|c|c|c|c|c|}
\hline & \multicolumn{2}{|c|}{ Model 1} & \multicolumn{2}{|c|}{ Model 2} & \multicolumn{2}{|c|}{ Model 3} \\
\hline & $B$ & S.E. & $B$ & S.E. & $B$ & S.E. \\
\hline \multicolumn{7}{|l|}{ Countries $^{\mathrm{a}}$} \\
\hline Switzerland & .13 & .16 & $.44 * *$ & .17 & $.96 * * *$ & .20 \\
\hline France & $-.56^{* * *}$ & .15 & $-.74 * * *$ & .16 & $-1.39 * * *$ & .19 \\
\hline UK & $-.75 * * *$ & .15 & $-.82 * * *$ & .16 & $-1.58 * * *$ & .19 \\
\hline \multicolumn{7}{|l|}{ Social position } \\
\hline Female & $-.37 * * *$ & .10 & $-.49 * * *$ & .11 & $-.41 * *$ & .13 \\
\hline Age & $-.02 * * *$ & .00 & $-.02 * * *$ & .01 & $-.03 * * *$ & .00 \\
\hline Education & $-.14 * * *$ & .02 & $-.12 * * *$ & .02 & $-.09^{* * *}$ & .02 \\
\hline National citizenship & $.91 * *$ & .29 & $.91 * *$ & .30 & .20 & .34 \\
\hline Unemployment history & .16 & .12 & .07 & .12 & .16 & .14 \\
\hline Income & $-.12 * * *$ & .02 & $-.10 * *$ & .02 & $-.12 * * *$ & .03 \\
\hline \multicolumn{7}{|l|}{ Anchoring (Self-appraisals) } \\
\hline Material insecurity & & & .04 & .08 & -.14 & .09 \\
\hline Physical insecurity & & & $.17 *$ & .07 & .01 & .08 \\
\hline Interpersonal trust & & & $-.22 * * *$ & .03 & .02 & .04 \\
\hline Political efficacy & & & $-.10 * * *$ & .03 & .05 & .03 \\
\hline \multicolumn{7}{|l|}{ Organising principles } \\
\hline \multicolumn{7}{|l|}{ Vertical differentiation } \\
\hline Institutional trust & & & & & $-.27 * * *$ & .04 \\
\hline System responsiveness & & & & & $-.09 *$ & .04 \\
\hline \multicolumn{7}{|l|}{ Horizontal differentiation } \\
\hline Material immigrant threat & & & & & $.73 * * *$ & .10 \\
\hline Cultural diversity threat & & & & & $.84 * * *$ & .10 \\
\hline$R^{2}$ Nagelkerke & .16 & & .21 & & .44 & \\
\hline
\end{tabular}

Note: ${ }^{a}$ Netherlands is the reference country category.

$* * * p<.001, * * p<.01, * p<.05$. 